\title{
CYTOLOGY OF THE ASCUS AND ASCOCARP DEVELOPMENT IN ACHAETOMIUM UNIAPICULATUM
}

\author{
J.N. RAI AND H.J. CHOWDHERY \\ Botany Department, Lucknow University, \\ Lucknow, India
}

(Received July 30, 1973)

\begin{abstract}
The paper deals with the development of ascocarp and nuclear behaviour during the development of ascus and ascospores in Achaetomium uniapiculatum. The ascocarp arises by the coiling of a hyphal branch. The septate ascogonial coil soon becomes surrounded by the vegetative hyphae forming a pseudoparenchymatous spherical body which in later stages gets differentiated into wall layers and central sporogenous tissue. The ascus originates from the penultimate cell of the crozier produced by the binucleate ascogenous cells. As in most of the ascomycetes, in A. uniapiculatum also, four divisions follow karyogamy resulting in binucleate ascospores, each mature ascospore only has a single nucleus the other nucleus probably degenerates. The haploid number of chromosome is $5(n=5)$.
\end{abstract}

The genus Achaetomium was established by RAI et al. (1) as a single genus of the family Achaetomiaceae, having ostiolate fruiting bodies devoid of hairy ornamentation with early deliquescing asci. Originally three species were described, namely, A. globosum, A. luteum, and $A$. strumarium. Later on two more new species $A$. macrosporum and $A$. uniapiculatum were added to this genus by RAI et al. (2), and by RAI and CHOWDHERY ( 3 ).

The present paper embodies a detailed investigation of the morphological development of ascocarp and the cytology of the ascus in Achaetomium uniapiculatum.

\section{MATERIAL AND METHODS}

The developmental stages of ascocarps were obtained by growing the fungus on thin oatmeal agar films prepared on sterilized microscopic slides under aseptic conditions. These were incubated at $28^{\circ}$ in a moist chamber. The slides were fixed at different intervals to obtain the various developing stages of ascocarps. These slides were examined under microscope after staining them with aceto-iron Haematoxylin. For microtome sections, the fungus was grown on oatmeal agar, the material was fixed in Form-acetic 
alcohol at desired stages, and sections of $8-10 \mu$ were stained in Haematoxylin. For nuclear divisions and other details regarding the development of ascus and ascospores, squash preparations were made with acetocarmine.

\section{OBSERVATIONS}

\section{Mycelium and hyphal fusion}

The fungus produces sufficient aerial mycelium on oatmeal agar. The hyphae are septate and multinucleate. Each cell of the hyphae contains 2-6 nuclei. The hyphae show frequent hyphal anastomosis and fusion (Fig. 13).

\section{Development of ascocarp}

The ascocarp initially appears as a distinct stout lateral branch from the mycelium, and it takes a deep stain in comparison to the rest of the mycelium when stained with aceto-iron-Haematoxylin (Fig. 1). It grows further and later becomes hook-like and it is cut off from the parent hyphae by a septum containing 3-8 nuclei with dense cytoplasm (Fig. 2). This hook elongates further, septation takes place, and a coil of 4-8 spirals is formed (Figs. 3-7, 14, 15). Each cell of the spiral is multinucleate with vacuolated finely granular cytoplasm.

From the basal cells of the coil, hyphae grow out to form a pseudoparenchymatous wall around the coil (Figs. 8-10). These septate slender hyphae continue to grow further, forming a several-layered thick pseudoparenchymatous wall. At this stage ascocarp is clearly distinguishable into two zones, the outer wall layer and the inner central core which later forms the sporogenous system (Figs. 11, 12, 17).

As development proceeds the wall is differentiated into two distinct layers, the outer layer which is 3- to 4-cell thick and consisting of somewhat thickwalled dark-coloured polygonal cells, while the inner layer contains tangentially elongated polygonal hyaline cells (Fig. 17).

After the differentiation of wall layers, cells of the central core start dividing in all directions producing the central sporogenous tissue (Fig. 18) and, at the same time, central core breaks and forms a loose mass of multinucleated cells (Figs. 18, 19). These multinucleate cells were pushed towards the base of the ascocarp due to inward growth of the inner wall layer cells (Fig. 20). Thus the ascogenous cells are differentiated only at the base of the ascocarp (Figs. 21-23). The ascogenus system is situated at the base of the ascocarp (Figs. 24, 25).

\section{Formation of ostiole}

Narrow hyphae round off from the cells of inner wall at the top of the ascocarp and becomes the periphyses (Fig. 20). The ostiole extends outwards as the neck of the ascocarp is formed due to the outward growth of the periphyses and outer wall layer cells. At maturity the ascocarp opens to the 

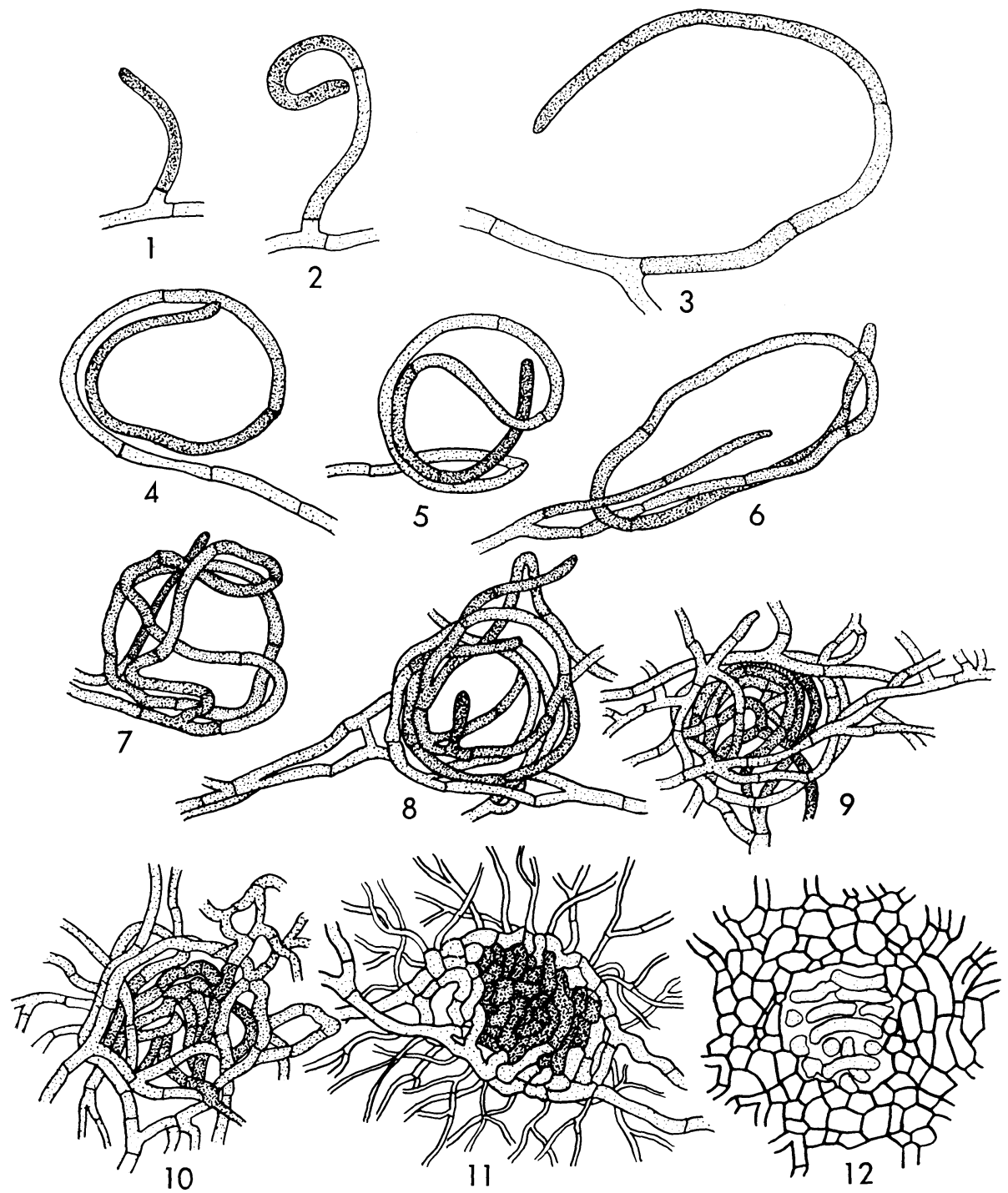

Figs. 1-12. Early stages of ascocarp development in Achaetomium uniapiculatum.

exterior through ostiole and by this time the periphyses appear to have undergone some dissolution (Fig. 24).

\section{Formation of ascus}

Binucleate ascogenous hyphae arise from the ascogeneous cells as small outgrowths and subsequently develop into crozier. The two nuclei of the 

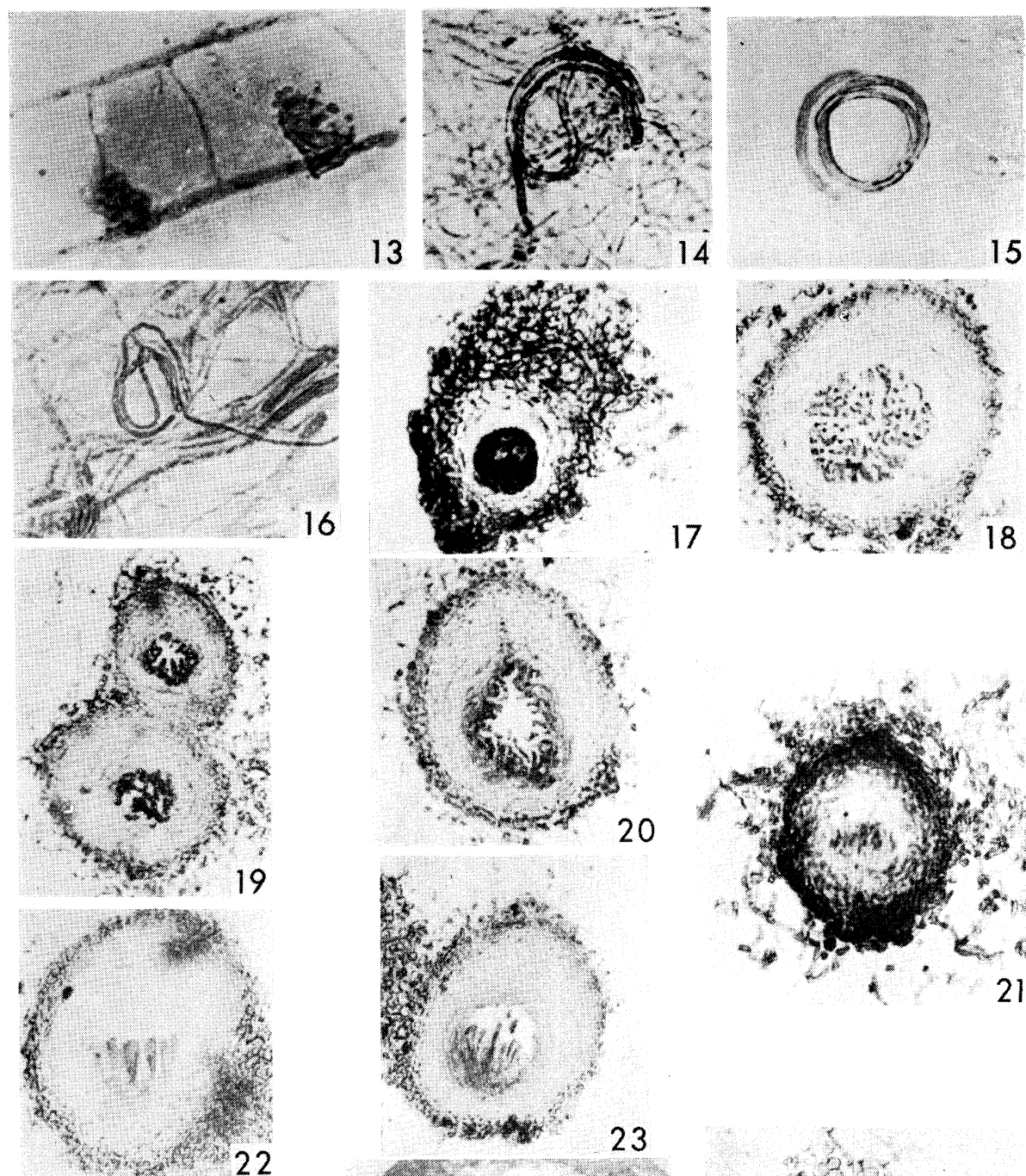

\section{5}
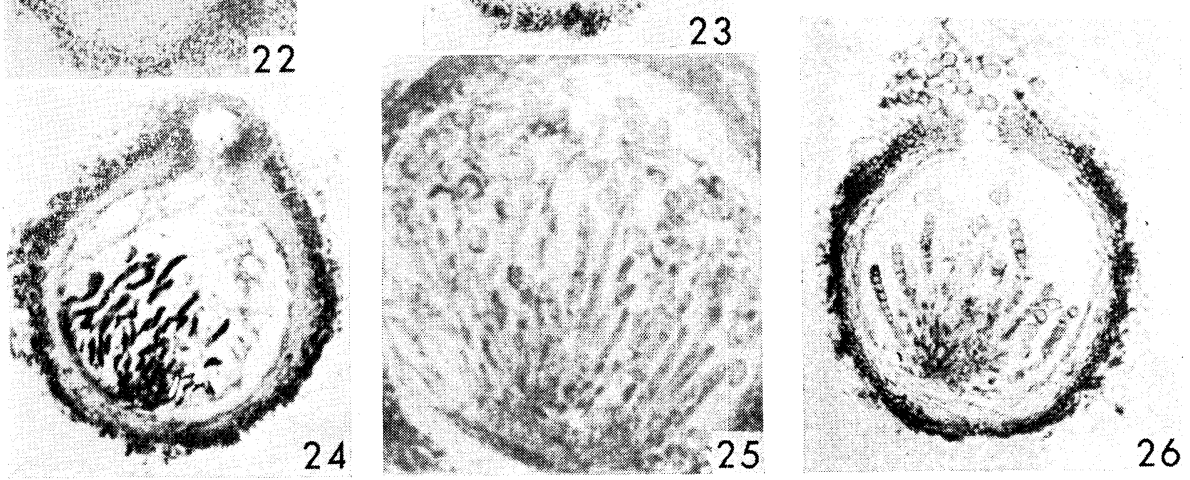
ascogenous hyphae divide mitotically (Figs. 27-29, 38, 39) and simultaneously the crozier becomes septate resulting in 3 cells. The penultimate cell of the crozier has two nuclei; the ultimate cell and antipenultimate one nucleus each. Later on, fusion of ultimate and antipenultimate cells results in a binucleate cell which can give rise to another crozier. Repeated occurrence of this phenomenon results in a cluster of croziers. The two nuclei of the penultimate cell fuse to form a prominent diploid nucleus (Fig. 40). Now the penultimate cell elongates and grows in size and becomes the future ascus (Fig. 30).

During the first nuclear division nucleus is seen in the centre of the ascus, with lightly stained chromatin network and a prominent deeply stained nucleolus (Figs. 31, 41). After a short period of rest the nucleus enters the meiotic division. The chromosomes are elongated and look more or less like threads during pachytene stage. The next stage which comes after the pachytene is diplotene during which the bivalents can be seen in the form of thick chromatin blocks and a deeply stained nucleolus (Fig. 42). Five bivalents are seen at diakinesis (Fig. 43). At metaphase I, a plate of five bivalents showing maximum condensation is present in the centre of the ascus, but the bivalents are so clumped that they are not distinct enough to be counted (Fig. 44). Anaphase I (Figs. 32, 45) is followed by telophase I (Fig. 46) showing two nuclei in the ascus. After the first karyokinetic division nuclei show interphase characterized by lightly stained chromatin network and a deeply staining nucleolus situated at the periphery of the nucleus. After the first

Figs. 13-26. Stages of ascocarp development in A. uniapiculatum.

13. Hyphal anastomosis. $\times 230$.

14-16. Ascogonial coil ; $14, \times 230 ; 15, \times 200 ; 16, \times 165$.

17. Young ascocarp differentiated into central sporogenous core and pseudoparenchymatous peridium. $\times 165$.

18. Division and breaking in sporogenous core. $\times 330$.

19. Dissolution of central cells. $\times 130$.

20. Development of basal ascogenous system and young periphyses. $\times 130$.

21-23. Development of young asci in basal fascicles; $21, \times 65 ; 22, \times 130$; $23, \times 100$.

24. Dissolution of periphyses and formation of ostiole. $\times 65$.

25. Basal ascogenous system in a ascocarp. $\times 100$.

26. Vertical longitudinal section mature ascocarp. $\times 75$. 

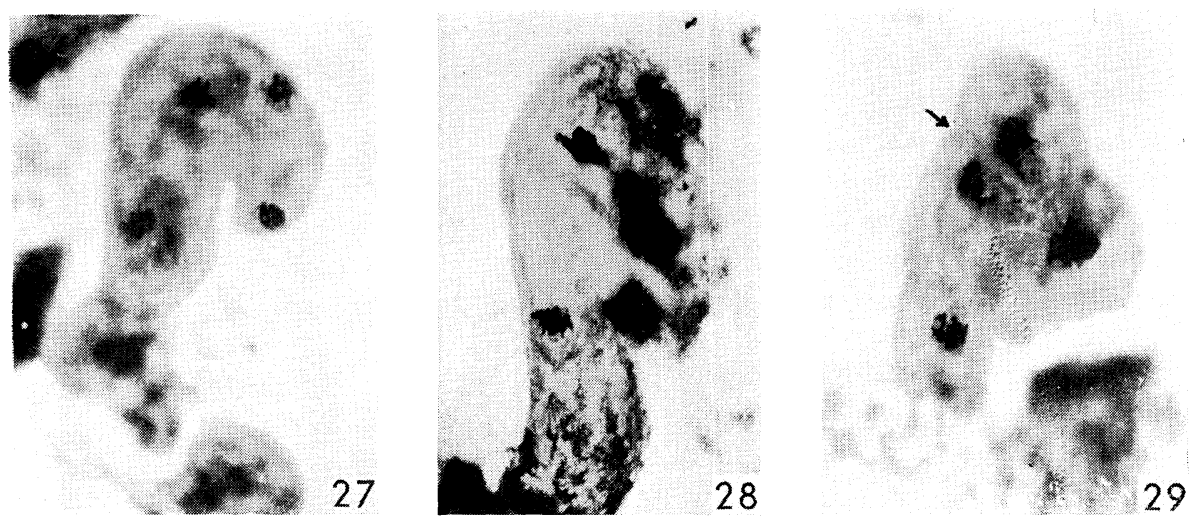

3

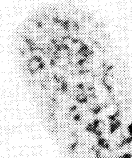

$+$

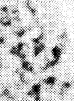

ing.
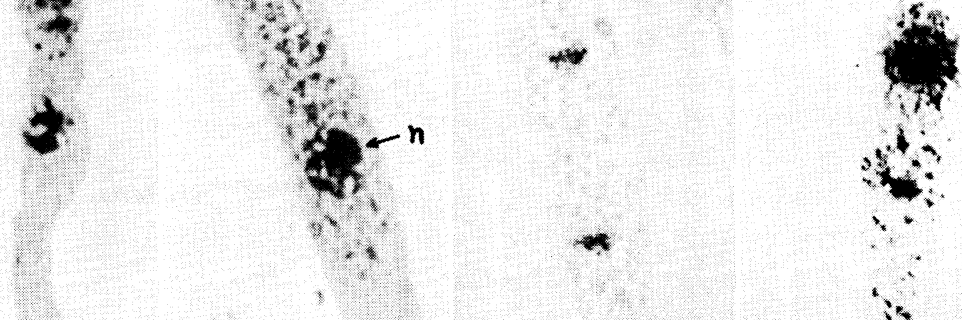

30

31

33

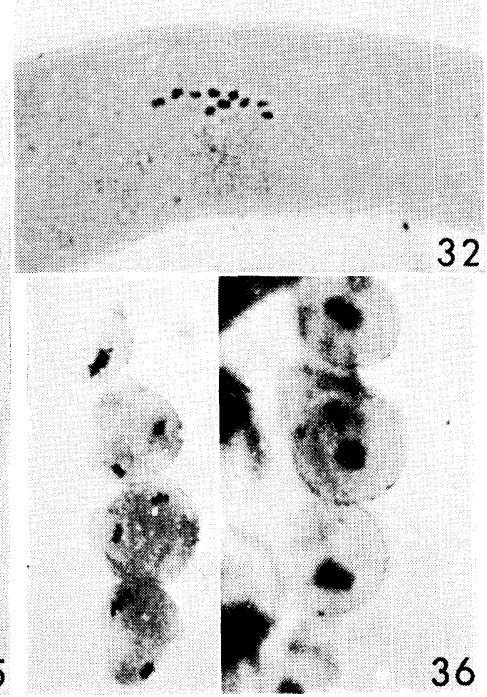

32

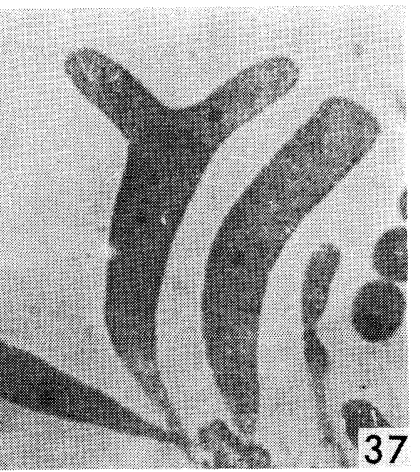


interphase the nucleus enters the second division. The chromatin network gradually becomes condensed. At metaphase II, two plates are formed with five chromosomes in each plate (Fig. 33). At anaphase II, the five chromosomes of both nuclei split into chromatids and the groups of five chromatids each move towards opposite poles (Figs. 34, 47, 48). The next similar repeated divison of these four nuclei results in the formation of eight daughter nuclei at telophase III (Figs. 35, 49).

At the end of the third division, new nuclear membrane did not appear and a cleavage in the cytoplasm of ascus appeared, separating eight ascospores (Figs. 35, 50). Subsequently one more nuclear division in ascospore resulted in producing binucleate, one-celled ascospores (Fig. 36). However, when the ascospores are mature only one nucleus is seen (Fig. 36), the other nucleus probably degenerates.

Ten chromosomes are seen well separated and distinct at anaphase I division (Fig. 32). Furthermore, five bivalents at diakinesis and also at metaphase are seen. Based on these observations, the haploid chromosome number of this species is $5(2 n=10)$.

Rarely an ascus was found with a bifurcated tip which resembles more or less the letter Y (Fig. 37), but the nuclear conditions of these asci and ascospores were not determined.

\section{Mature ascocarp}

The wall of a mature ascocarp, in a vertical longitudinal section shows three distinct layers. The outermost layer is $1-3$ cells thick and the cells

Figs. 27-37. Stages of ascus and ascospore development in A. uniapiculatum.

27-28. Crozier at conjugate division; $27, \times 1,640 ; 28, \times 1,600$

29. Two nuclei just before fusion in penultinate cell (arrow). $\times 1,500$.

30. Young ascus. $\times 500$.

31. Prophase, with a large, darkly stained nucleolus (marked $n$ ). $\times 750$.

32. Anaphase I. $\times 1,100$.

33. Ascus with chromosomes oriented at metaphase II. $\times 750$.

34. Chromosomes oriented at metaphase III. $\times 500$.

35. Eight-nucleate ascus showing cleavage in the cytoplasm. $\times 500$.

36. Young and mature ascospores showing two and one nuclei, respectively (binucleate ascospores indicated by arrow). $\times 290$.

37. An abnormal Y-shaped ascus. $\times 500$. 


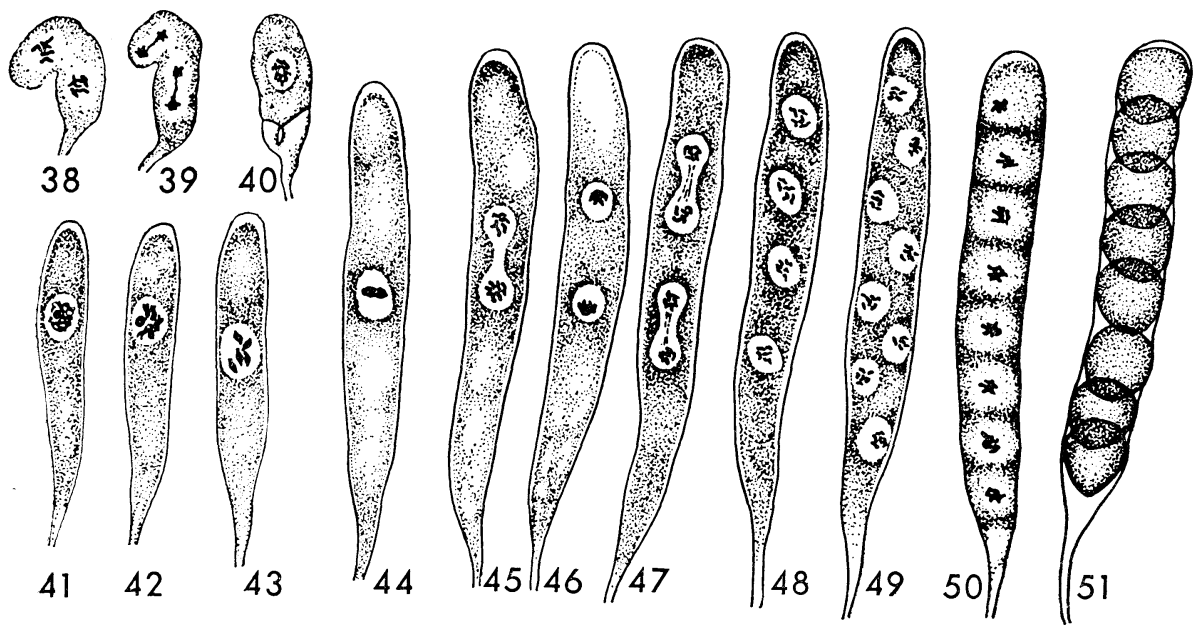

Figs. 38-51. Diagrams showing stages of the ascus and ascospore development in A. uniapiculatum.

38. Prometaphase of the conjugate mitotic divisions in the crozier.

39. Late mitotic anaphase in the crozier.

40. Early post fusion nucleus.

41. Prophase.

42. Diplotene.

43. Diakinesis.

44. Mataphase I.

45. Anaphase I.

46. Telophase I.

47. Anaphase II.

48. Telophase II.

49. Telophase III.

50. Cleavage in the cytoplasm of ascus.

51. Mature ascus with 8 ascospores. 
are heavily pigmented. The next layer is $2-4$ cells thick and the cells here are relatively thin walled. These two layers constitute the outer wall of the ascocarp. The innermost layer lines the entire ascocarp cavity and consists of 2-3 layers of cells which are tangentially elongated. The 8-spored asci nearly fill the perithecial cavity (Fig. 26).

\section{DISCUSSION}

Cytology of the ascus in the family Achaetomiaceae has been reported for some members recently by RANGA RAO and MukeRJI $(8,9)$. However, the development of ascocarp has so far not been investigated at all and hence a detailed study on the development of ascocarps and cytology of ascus in Achaetomium uniapiculatum was undertaken. The development of ascocarp initials in Achaetomium uniapiculatum is very much similar to that found in Anixiella indica (4), Sordaria fimicola (5) and Gelasinospora calospora (6). The ascogonial coil generally arises as a result of the coiling of a stout, deeply staining multinucleated lateral branch from the mycelium. The usual septation of the coil takes place and, with the help of vegetative hyphae, it forms a several layer thick wall of the ascocarp. Plasmogamy usually occurs by the anastomosis of two vegetative hyphae, which has been frequently observed in these investigations. Hyphal anastomosis has also been reported in many species of Neurospora (7), Anixiella indica (4), Sordaria fimicola (5), and Gelasinospora calospora (6).

In $A$. uniapiculatum the ascus originates from the binucleated penultimate cell of the crozier. Development of the crozier from the binucleated ascogenous hypha is typical of the Ascomycetes. The nuclear behaviour in the ascus of A. uniapiculatum is quite similar in its main features to that of many investigated members of the Ascomycetes (10-13). The young ascospores are uninucleate, becoming binucleate following mitosis during maturity. One of the nuclei subsequently degenerates and the mature ascospores are uninucleate as reported in Ascotricha guamensis (14) and Hypoxylon rubiginosum (12).

All the sequential stages in ascus cytology resemble those described for Achaetomium globosum, A. luteum, and A. strumarium by RANGA RAO and MUKERJI $(8,9)$. In their study of the cytology of ascogenous system for all these above-mentioned species the haploid chromosome number has been reported to be 7 . On the basis of haploid chromosome number, they $(8,9)$ have drawn a possible relationship of family Achaetomiaceae with the family Chaetomiaceae because the haploid chromosome number in members of Chaetomiaceae is also reported to be 7 . However, the present study has revealed the haploid chromosome number in $A$. uniapiculatum to be $5(n=5)$, indicating thereby that too much reliance cannot be placed on chromosome number when discussing the relationship. 


\section{REFERENCES}

1) J.N. Rai, J.P. Tewari, and K.G. Mukerji, Can. J. Bot., 42, 693 (1964).

2) J.N. RAI, K. WADhWANI, and J.P. TEWARI, Indian Phytopathol., 23, 54 (1970).

3) J.N. RaI, and H.J. ChowdherY, Curr. Sci., 40, 412 (1971).

4) J:N. Rai and K. Wadhwani, J. Gen. Appl. Microbiol., 16, 251 (1970).

5) A.J.H. CARR and L.S. Olive, Am. J. Bot., 45, 142 (1958).

6) J.J. Ellis, Mycologia, 52, 557 (1960).

7) B. Colson, Ann. Bot., 48, 211 (1934).

8) V. Ranga Rao and K.G. Mukerji, J. Gen. Appl. Microbiol., 17, 311 (1971a).

9) V. Ranga Rao and K.G. Mukerji, Bot. Gaz., 132, 179 (1971b).

10) J.R. Singleton, Am. J. Bot., 40, 124 (1953).

11) B.M. BERKSON, Mycologia, 58, 125 (1966).

12) J.D. Rogers, Mycopathol. Mycol. Appl., 38, 215 (1969).

13) V. Ranga Rao and K.G. Mukerji, Trans. Myco. Soc. Japan, 13, 105 (1972).

14) V. RANGA RAo and K.G. MukerJI, Mycologia, LXII, 301 (1970). 